\title{
Chimpanzees, Bonobos, \& Humans: A Contrast in Behavior \& Evolutionary Significance
}

\author{
Ryan J. Trubits \\ Peace Corps, stationed in Guinea, Peace Corps Headquarters 1111 20th Street, NW Washington, DC 20526
}

Received 5 September 2011; accepted 4 November 2011

\section{ŠIMPANZI, BONOBOVÉ A LIDÉ: ROZDÍLY V CHOVÁNÍ A JEJICH EVOLUČNÍ VÝZNAM}

ABSTRAKT Antropologové uznávají jak blízkou podobnost, tak i výrazné rozdíly mezi lidmi a lidoopy, a z nich jmenovitě šimpanzi a bonoby. Vedle uznání zjevných biologických charakteristik bylo také třeba, aby primatologové prozkoumali psychologické a sociální podobnosti mezi lidským živočichem a dvěma druhy rodu Pan. Jane Goodallová byla průkopnicí dlouhodobého pozorování divokých šimpanzů na krátkou vzdálenost $\mathrm{v}$ jejich přirozených prostředích. Výsledky převratných výzkumů Harolda Coolidge a Franse de Waala přispěly podobným způsobem k pochopení a porozumění bonobů. Tyto studie zřetelně svědčí o nápadném kontrastu mezi agresivním šimpanzem a mírumilovným bonobem. Náš vlastní druh nadto sdílí některé psychologické a sociální aspekty s oběma zmíněnými pongidy. Antropologové tedy dnes mohou s jistotou zasadit všechny tři druhy do evolučního rámce.

KLÍČOVÁ SLOVA agrese; rozdílnost v chování; mozek; prostředí; evoluce; mezidruhové rozdíly; sex; násilí

\begin{abstract}
Anthropologists recognize both the close similarities and distinct differences between the human species and the great apes, especially the chimpanzee and the bonobo. Besides acknowledging the obvious biological characteristics, primatologists needed to also investigate the psychological and social similarities between the human animal and the two Pan species. Jane Goodall pioneered the close-range and long-term observations of wild chimpanzees in their natural habitats. Likewise, Harold Coolidge and Frans de Waal contributed to understanding and appreciating bonobos as a result of their ground-breaking research. These studies clearly attest to a striking contrast between the aggressive chimpanzee and the peaceful bonobo. Furthermore, our own species shares some psychological and social aspects with both of these pongids. Consequently, anthropologists can now confidently place all three species within an evolutionary framework.
\end{abstract}

KEY WORDS aggression; behavioral diversity; brain; environment; evolution; interspecies differences; sex; violence

\section{INTRODUCTION}

The study of social behavior in primates is imperative in terms of humans coming to accept their emergence from a fossil apelike form. Researching interspecies diversity in chimpanzees and bonobos has impacted the way science understands the evolutionary forces that took place at the origin of Pan's divergence. These species are a window into our past and the great apes are the closest living links we have to our extinct ancestors. They make excellent models for identifying our ancestral traits and allow researchers the ability to rationally understand, appreciate, and speculate on how our fossil ancestors developed into the complex human species of today.

\section{EARLY CHIMPANZEE STUDIES BEFORE JANE GOODALL}

The first documented chimpanzees brought to Europe came from Angola and were presented to the Prince of Orange in 1640 (Boesch et al 2002). For the next three centuries, explorers from Europe continued to shoot and kill chimpanzees in order for them to be shipped back to Europe to be studied. There was a particular interest in investigating the anatomy and eidonomy of chimpanzees. As interest peeked for this species, trappers became focused on capturing and bringing live specimens to Europe so that researchers could observe their social behavior. With this opportunity to view this 
species in captivity, people realized that chimpanzees shared many similar behavioral traits to our species; they are able to create and manipulate tools, express facial emotions, and are natural problem solvers. While these discoveries about captive chimpanzees shed light on the potentiality of chimpanzee research, only recently has studying pongids in the wild been a common practice.

\section{JANE GOODALL'S EARLY OBSERVATIONS}

Jane Goodall's research of wild chimpanzees at Gombe Stream National Park, Tanzania, in 1960, transformed primate research studies as we know it. Sponsored and mentored by the late Louis S. B. Leakey, Goodall has devoted over 45 years of her life to studying the social interactions of debatably the pongid most similar to humans. It was Goodall's discovery of chimpanzee termiting that changed science's understanding of what is classified as distinctly human behavior and allowed her to continue her research for the National Geographic Society. In reaction to Goodall's discovery, Louis Leakey stated that science "must now redefine man, redefine tool, or accept chimpanzees as human" (Goodall 2000).

Goodall's observations of hunting fish with pipe-like sticks, the extraction of honey from hives, and the use of leaves as sponges expressed the unique social behaviors of chimpanzees. While tool usage varies from group to group, there is evidence proving that this pongid critically thinks in order to solve problems. These techniques are learned generally by an individual in a community and are later learned by others through imitation. Members observe the intrinsic benefits that a new skill brings about and will replicate said behavior. Chimpanzees have fascinating social behavior patterns. They live in communities that vary from 10 to 100 members and subsist in diverse environments that provide a mosaic of varying social behavior practices. Chimpanzee groups are classified as fission-fusion societies. Goodall's observations shed light on the disparity in male and female roles in a community. She determined that males form close bonds with their male conspecifics; natal dispersal is uncommon in males, which promotes close social bonds between males. The males of a community are very social with one another; they spend a considerable amount of time grooming, hunting, and protecting their territory. Their social alliances are a contributing factor in the success of a community.

Female chimpanzee life focuses primarily around caretaking for their offspring; parenting is a fulltime commitment. Mothers devote a considerable amount of their life being pregnant or caring for infants who are completely dependent on their mothers for up to six years. If it was not for their time raising offspring, then chimpanzee infants would not receive the attention they need in order to survive. This close and personal relationship is maintained for the remainder of the child's and mother's life. Being a successful mother, who mates with high-ranking males, has a direct correlation to reproductive success and the passing on of one's genetic traits.
Outside of caring for one's offspring, mothers must provide themselves and their young with sustenance. Accessing essential resources has a direct impact on reproductive success and longevity. Females in chimpanzee communities have little to no social contact with each other. This social behavior can be explained due to both limited feeding sites and resources. This causes members to scramble for food and the environmental conditions have caused social relationships between female chimpanzees to be limited. With the need to constantly search for resources, females are not given the opportunities to be prosocial which generally takes place between male chimpanzees. In sharp contrast, acts of grooming, hugging, and vocalization cement alliances which promote equality in a community of female bonobos.

Chimpanzees practice a predominately female biased dispersal. Females are free to leave societies and join other groups; it is advantageous to a chimpanzee community that females leave their natal community. This dispersal avoids the possibility of incest. Leaving a natal community is possible for females because the sexual swelling of a female's hindquarters is seen as a "passport" into other communities. This pink footballsized sexual sac is appealing to males and makes access into a new community probable. Usually individuals that leave their natal region are vulnerable to leaving home because they are unaware of the locations of food sites, and are at risk of aggression from conspecifics. Solitary females that leave their natal community's range will cross borders and come into contact with patrolling males from neighboring groups. Males are less likely to attack a visibly estrous female than one that may already be pregnant.

The female's estrous cycle is on a 34 to 35 day cycle. For nine to ten days the bare skin on her bottom becomes pink and swollen; this is a result of sexual swelling on the female's hindquarters. This hormonal reaction is triggered and is a signal which expresses her sexual availability and also when conception is optimum. The membrane inflates from an increase in hormones. Scientists believe that females are key to the success of chimpanzee population groups. Females sexually select males that are considered most fit. Researchers believe the swelling is an adaptation that promotes reproductive success and also competition among males.

\section{JANE GOODALL'S LATER OBSERVATIONS}

Territory while not being clearly marked is one of the sole reasons for violence in chimpanzee society. Jane Goodall reported in her testimonies that brutal displays of aggressive acts escalated to even murder when male chimpanzees strayed from their natal group. Males that drift away from a group are usually killed and eaten. Intergroup violence customarily takes place only when a rival group outnumbers the neighboring community. Territory expansion is important for increasing community resources. Extending borders improves access to suitable mates, fruit trees, sources of water, and termite hills. 


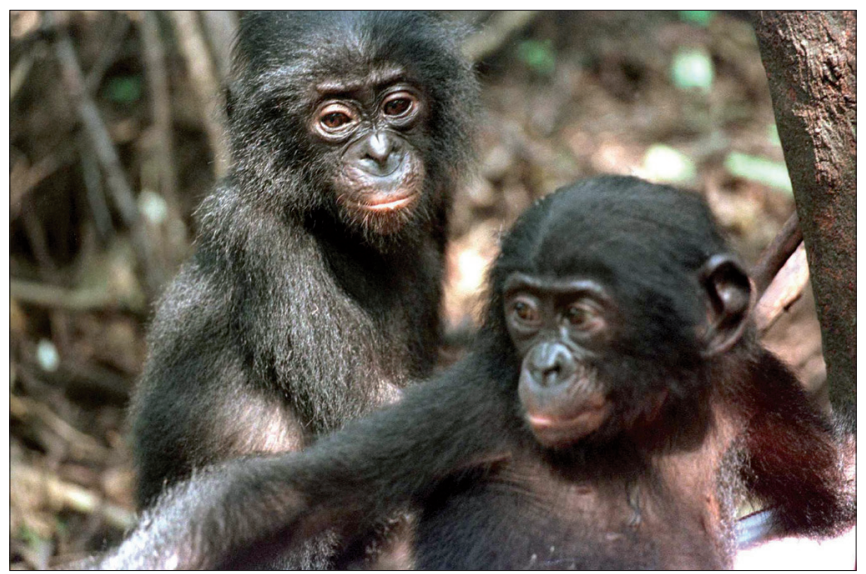

Fig. 1. Peaceful infant bonobos.

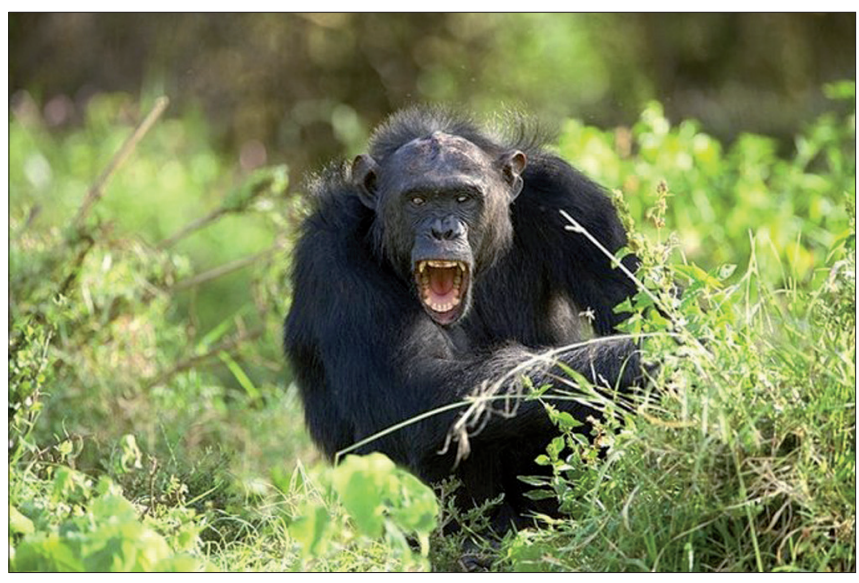

Fig. 2. Charging chimpanzee.

Illustrations 1 and 2 demonstrate a contrast in social behavior between the aggressive chimpanzee and the peaceful bonobo.

On January 7, 1974 the perception of chimpanzees changed forever. Goodall's team in the Gombe discovered that the Kasakela group systematically eliminated the neighboring community of the Kahama. Researchers found particularly disturbing that this bordering community once was a part of the Kasakela. These groups had once lived in peace with one another. Ordinarily, violence is not prevalent in chimpanzee communities but in this unique case the chimpanzees of the Kasakela group deliberately raided the territory with apparent intention of acquiring resources through the use of "coalitionary aggression" (Goodall 1986, Wrangham 1999). Similar to humans, chimpanzees have the capacity of treating members of their own species as inferior. Group solidarity and identification is extremely influential in perception; chimpanzees that once lived in peace with one another almost overnight became enemies because of conflicting interests which lead to "dechimpization" (de Waal 2005).

Chimpanzees live in complex and highly stratified-patrilineal societies with leaders dictating social convention. Males grow up with one another and form close social bonds with their cohorts. These close affiliative relationships permit individuals within a group to hunt and search for resources. On hunts males share a sense of euphoric excitement which is demonstrated in grinning, embracing, the standing up of body hair, and gesturing to other members of their unit (Wilson 2003). In these efforts alpha males gain precedence over resources, especially the access to estrous females. The ability for males to maintain support through mutual assistance and affiliative interactions with other males plays a critical role in the general fitness of a male.

Successful border patrols and agonistic contexts will result in meat sharing or the exchange of resources. Sharing meat with allies strengthens social cohesion and also entices females to fulfill male sexual gratification (Mitani 2009). Chimpanzees will also fight for resources with neighboring groups and are extremely hostile toward outsiders because they are xenophobic.

Chimpanzee hierarchies are not static; there is constant strug- gle for claiming alpha-male status. Young adult males do not inherit their ranks from their fathers. They strive to oust leaders by forming coalitions with rivals to cause upheaval to the social order. Alliances between chimpanzees customarily take place between two high-ranking opponents. However, these partnerships are not permanent. Support can change when it is pertinent to shift support for another male who gives a male chimpanzee the best opportunity to gain access to estrous females. Older males unable to physically outperform against young males must rely on their social networking abilities in order to secure their status in the community and obtain adequate mating opportunities.

When male chimpanzees take over a community it is natural that they deliberately kill off all infants that are not sired by them. This is known as infanticide; males will intentionally kill off the previous leaders offspring in order to cause females to end weaning and begin cycling sooner. As a result, males are able to have access to mates, pass on their genes, and eliminate males that could challenge their leadership in the future. Female chimpanzees try to protect their infants but males are larger and by far stronger. That is why many female chimpanzees remain isolated from large communities for the initial years of their infant's development in order to avoid aggressive males.

Fatal coalitionary killing attacks are also present within intragroup contexts such as in Ngogo (Watts and Mitani 2004) and also in Budongo (Fawcett and Muhamuza 2000). In both cases adult male members inflicted fatal wounds on a conspecific within their own unit-group. When violence occurs within a community, it is usually pertaining to a coalition attempting to overthrow an alpha male. In these reports subordinate members did not challenge a higher-ranking male's hierarchical status. The victims in both instances were lowranking members of the community, and made no attempts to cause social upheaval within the group. GRA (Ngogo) and Zesta (Budongo) were socially marginal, having little association with other males, specially in the act of grooming community members. GRA and Zesta were both potential 


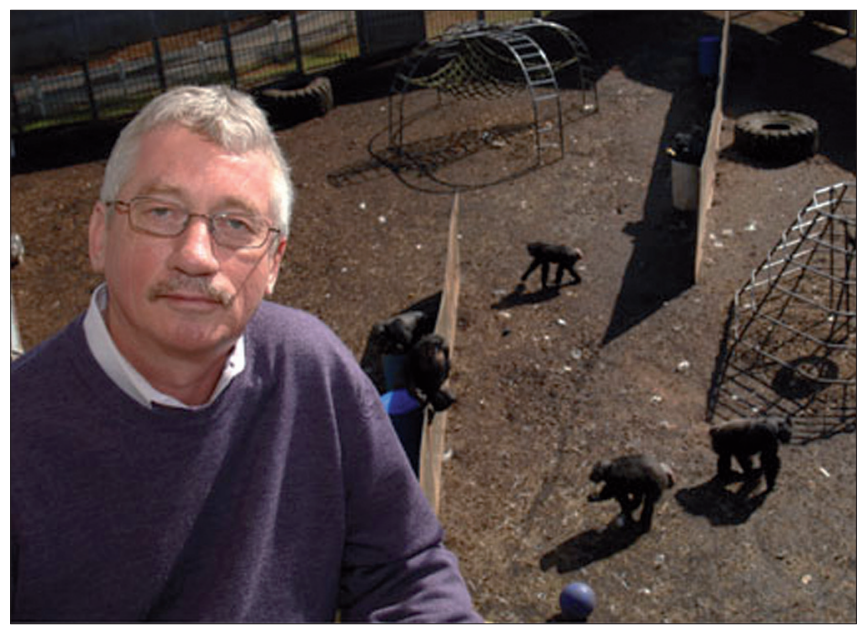

Fig. 3. Frans de Waal at Emory's Yerkes National Primate Research Center. Photo from Emory Magazine, Spring 2006, by Paige P. Parvin, associate editor, $96 \mathrm{c}$. Photograph by Kay Hinton.

candidates for mating with females. It is clear that GRA's introverted behavior directly impacted on his survivability. Few grooming partners, especially in the case of GRA, impacted the chimpanzee's ability to form "influential allies" (Watts 2003). The actions that were taken to eliminate GRA were planned and acceptable by members of the community. These social factors provided an atmosphere of high mating competition, and as a result losing one male relatively low on the social hierarchy meant that GRA was disposable (Watts 2003). Males targeted him in order to eliminate competition for the access to females.

In Ngogo and also Budongo group members ganged up on the lower-ranking males. There were particular individuals as the primary attackers, but there were no chimpanzees who attempted to stop the acts of aggression from taking place. Members of high ranking status, adolescents, and females were bystanders observing the acts performed on conspecifics. Females are the limiting resource for males and they determine reproductive success (Strier 2007); this is the primary cause for chimpanzee intergroup aggression and also intragroup hostility. Since GRA had copulations, males appeared to resent his success with females. While GRA did not challenge the order of higher ranking males, participants in the act might have perceived GRA as a threat to their status. This was evident based on previous coalitionary attacks performed on GRA (Watts 2003). The documentation of these events emphasizes the true driving force of natural tendencies which is individual fitness in male chimpanzees.

\section{EVOLUTIONARY INTERPRETATION OF CHIMPANZEE BEHAVIOR}

Since the 1990s, field research on chimpanzees has advanced in several ways. First, several projects have lasted long enough to document whole life histories of known chimpanzee communities. Second, new study sites have been established with niches of 'unusual' environmental features. Third, researchers have incorporated neighboring communities to examine intrapopulation variability. Fourth, analysis of the genetic relationships among group members has revealed the history of group members and the fitness consequences of social and reproductive strategies. Finally, a new generation of researchers has entered the arena, challenging old themes with new hypotheses and techniques.

These field studies where then later collaborated at the turn of the century. Anthropologists demonstrated that natural social behavior patterns vary among different wild chimpanzee groups. Differences in the behavioral repertories were due to the geographical isolation of chimpanzee communities. Researchers from seven major long-term studies synthesized their information which accumulated over 151 years of chimpanzee observation. Over 39 different behavioral patterns were identified including the use of tools, grooming, and courtship behaviors. Social actions were classified as either customary, habitual, or absent. The ecological conditions played a major factor in the existence of behaviors. The discovery of these diversified behaviors is "highly distinctive, a phenomenon characteristic of human cultures but previously unrecognized in non-human species" (Whiten et al 1999).These findings caused scientists to reinterpret what is defined as culture. In this instance, chimpanzee communities are learning through transmitting information between one another both socially and observationally. While transmission of behavior is common in the animal kingdom it is usually only a single behavioral pattern: "chimpanzees have indicated that multiple behavioral variants may exist" (Whiten et al 1999).

Another major topic of discussion for anthropologists has been determining why chimpanzee conduct has promoted aggressive behavior. Researchers have presented that selection has favored males that can control limited resources such as mates and food. This has directly impacted individual fitness. Cooperative behavior in chimpanzees has been conducted in laboratories in order to understand the inner psychology of our living evolutionary cousin. Research conducted by both Joan Silk et al (2005) and later Keith Jensen et al (2006) concluded that chimpanzees made choices solely on personal gain. There was no regard for the fitness of conspecifics (Jensen et al 2006). Jensen's study was broken down into three experiments. Researchers placed chimpanzees in a controlled environment in which subjects were forced to decide on the outcome of their general welfare and also the outcome of a conspecific. The first experiment tested for direct fitness: selfishness and mutualism. The two remaining experiments tested indirect fitness in which the chimpanzees had the choice to provide food solely for another chimp (altruism) or to prevent the conspecific from receiving any benefit (spitefulness). The experiments concluded that chimpanzees are ego driven and not concerned with the general benefit of others. Jensen's test utilized W.D. Hamilton's fitness matrix, which allowed for a polarizing behavior model and gave chimpanzees the choice in their outcome. The goal of the experiment was to test if there was a propensity in chimpanzees to aid conspe- 
cifics in need which tested Ernst Fehr's proposition that "altruism as exhibited by humans has been claimed to be unique in the animal kingdom". Each experiment was constructed to isolate two potential decisions. The design of the experiment forced subjects into an outcome. Even if chimpanzees were inactive, their behavior resulted in a positive or negative outcome. The experiment held individuals accountable for their decisions. As a result, this provides experimenters with direct assessment of mutually incompatible behavior strategies (Jensen et al 2006). In contrast, Joan Silk's (2005) experiment resulted in an analogous outcome but failed to hold the chimpanzees accountable for the consequences of their choices and the impact that would have on conspecifics.

In both experiments, outcomes were similar. When chimpanzees were placed in situations pertaining to food, they were only interested in their own personal needs. Even when chimpanzees were aware that they had control over the outcome of a conspecific's fitness, it did not impact their decision making (Jensen et al 2006). These scientific experiments provide researchers with important insights on chimpanzee psychology and social behavior, while further supporting the impact that limited resources have on competition in chimpanzees.

\section{EARLY BONOBO STUDIES}

Bonobos were first discovered in the 1920s, during the age of colonialism, by Belgian hunters. Science's first skeletal evidence was from the remains that these explorers sent from the Congo to the Belgium Kingdom. They were scientifically described in 1929 by Schwartz. Since the 1930s, bonobos were claimed to be a sub-species classified as pygmy chimpanzees. They were identified as their own species in 1933 by Harold Coolidge, an American anatomist, who claimed that the species was structurally different from the chimpanzee. The major anatomical differences between bonobos and chimpanzees is that bonobos have a slender frame and males are only slightly larger than females. From the neck up, bonobos resemble chimpanzee. Males are more robust than females, with larger canine teeth. From the neck down, males and females are almost identical. As a result of two to three million years of evolutionary isolation, the common ancestral species specialized to form the modern chimpanzee and bonobo.

Behaviorally these species could not be any different. The first major study that helped shed light on this behavioral disparity was performed in the 1930s by Eduard Tratz and Heinz Heck at the Hellabrunn Zoo in Munich. Their eight point behavioral template isolated the sexual, aggressive, and vocal expressions of these species. This study was sadly disrupted due to the break out of World War II. This setback has been one of many in the search for understanding and appreciating this pongid.

The first field studies of living bonbos in their natural environment began in 1972, pioneered by Toshisada Nishida. His efforts provided science with a survey of the west bank of Lake Tumba. That same year, a team from Yale University

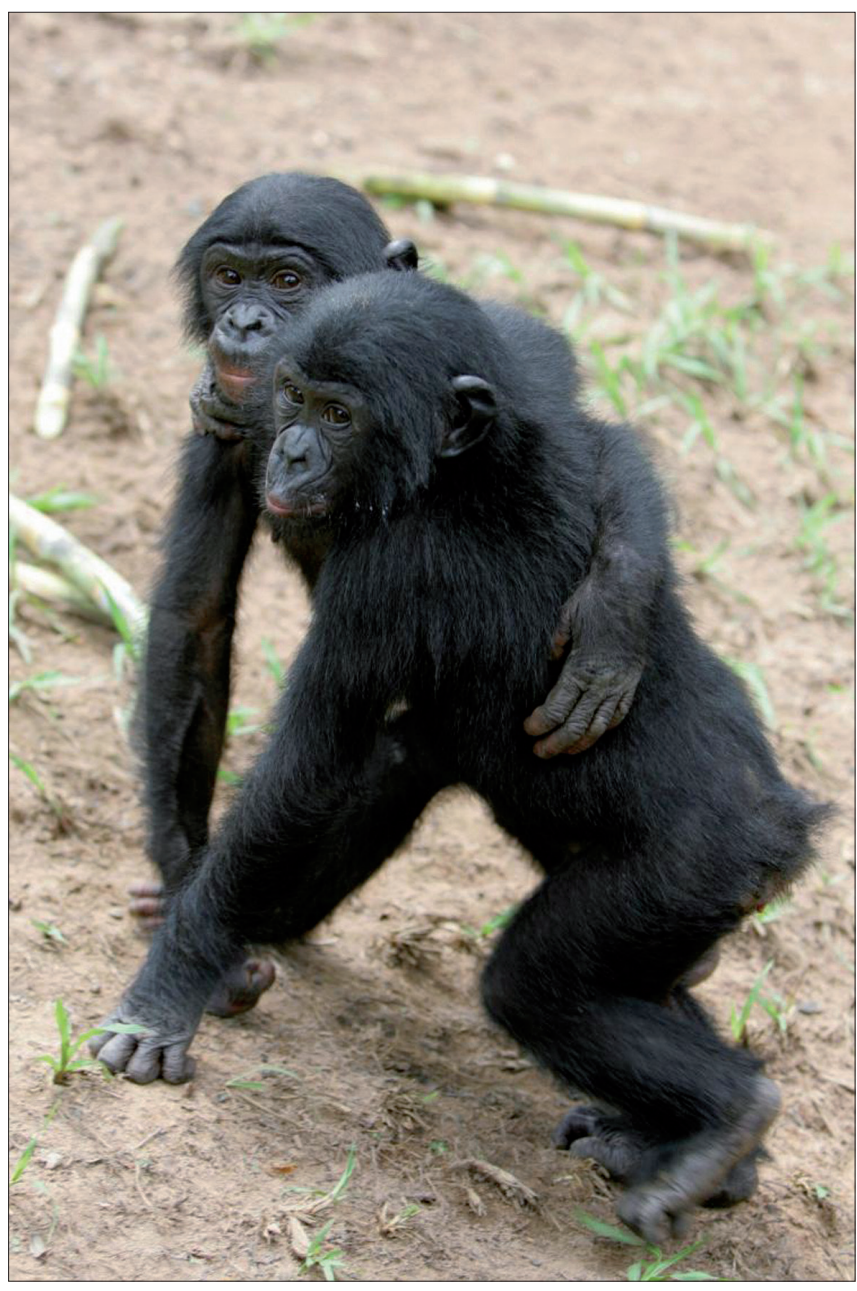

Fig. 4. Two bonobos embracing each other.

began a two-year study at Lake Tumba; which is considered the first field study site. In 1973 a comprehensive study was performed by Takayoshi Kano; his work was the first extensive long-term field site.

Bonobos have been one of the most difficult apes to study. Research has been restricted for many reasons. Bonobos are a shy and timid species, habituating populations takes time in order to observe them. Sites such as Wamba utilized sugarcane to entice bonobos, which made bonbos more prone to approach, allowing researchers the opportunity to study them at a closer proximity. Since 1976, this study site has focused its research on the various aspects of bonobo ecology and behavior.

Another challenge in researching bonobos is their environment. The species resides in the second largest rain forest in the world. It is an environment that is isolated and densely covered by a tropical forest. The Democratic Republic of Congo is 80 percent covered by tropical forest. The size of the country is deceiving; to the eye one may think the DRC is small, due to its size on a map, but in actuality, it is about the size of England. Access to this remote land is a challenge in itself, as one must hike through the rainforest or paddle down narrow river channels. 
As long-term field studies began to make progress civil war broke out in the Democratic Republic of Congo in 1991. The political unrest of this country once again set back the opportunity to understand this pongid's social behavior. Bonobos are indigenous to this region and there was no access to safe study sites. During the early 1990s new and exciting findings were made but then a long-lasting civil war took place from 1996-2002. Many primatologists feared that the bonobo species would decline significantly in numbers or become extinct. Fortunately, the species survived the acts of human violence, and researchers were able to continue their studies in 2002. In response to the aftermath of the Democratic Republic of Congo's political turmoil, science has now made a more conscious effort to examining the total range of this pongid and also to working with local communities to protect the global range of this endangered species.

\section{MAKE LOVE NOT WAR}

The natural environment has played a significant role on developing bonobo male and female social and emotional patterns. Resembling chimpanzees, bonobos live in large, multimale, multi-female communities in which males remain in their natal groups and females disperse before or after reproduction. In contrast to chimpanzees, the bonobo's tranquil environment permits female bonobos to create alliances with unrelated females in other groups. Bonobos live in a foodrich environment with herbaceous vegetation in their diet, in addition to fruit sites, which reduces the risk of competition at feeding sites for large groups compared to chimpanzees.

Though the majority of their diet is fruit, bonobos are also known to consume small mammals, insect larvae, earthworms, honey, and eggs (de Waal, Lanting 1998). Unlike chimpanzees, bonobos do not collaboratively hunt mammalian prey, but food sharing is present between individuals (Boesch et al 2002). Because of the relative richness of their habitat and availability of food sources, there is little constraint on bonobo group size. This has lead to a decrease in intraspecific feeding competition and heightened sociality, especially among females.

Male bonobos do not have the same social dominance that is present in chimpanzee communities. Chimpanzee behavior has evolved to promote opportunists who take control over their own status. Dominance hierarchies in bonobo communities are weak and almost nonexistent. The reason for this diminished competition is due to the frequency in opportunities to mate with females, female preference in choosing a suitable mate, and also the importance of maternal support in obtaining rank (Furuichi, Thompson 2008). Takeshi Furuichi has distinguished the significance of three maternal support classes in the male bonobo linear rank hierarchy: males that are raised by young mothers who assist in resolving aggressive interactions with other males will attain higher ranks than males born to older mothers whose ability to provide support is limited. The lowest ranking males are ones who are orphans. In particular, those who are left isolated and forced to take care of themselves will struggle to receive the proper nutritional support, which would normally be given during nursing, and also the challenge of establishing their place in a community which is extremely difficult to overcome. The reason male status is so dependent on their mother's assistance is due to the inability for males to form coalitions.

Mothers have an indirect incentive to promote their son's rise in status because it promotes her own lineage via the children her son will sire: "natural selection must have favored mothers who actively assisted their son's status quests." (de Waal 2005). The importance of obtaining high rank status for males greatly impacts female tolerance which allows them to have access to food and sex partners.

Bonobo communities are matrifocal with a rigid female hierarchical structure. Alpha status is obtained through maturity and generally lost due to illness or death. As a result, ambitious females are unlikely to rise in status at a young age. Having alpha status entails access to ample food sources, highranking males, and grooming partners. Static unity between unrelated females has allowed for female dominance in bonobo society. With this close social bonding, females are able to control bonobo communities through the regulation of food, protection of infants, female dispersal, and young male hierarchical rank. These female alliances have an important role in the successful immigration of females who enter into another community. Immigrant females shadow older well established female residents to gain acceptance into the society. Females are invited to participate in community activities when an older female invites an outsider to sexually interact with them. This entails rubbing their genitals against one another while facing each other.

G-g rubbing, genital-genital rubbing, is not limited to newfound friends. Sex has spilled over to all parts of social functions. It is a form of handshake as a casual quick greeting. Making other individuals in a community comfortable is done by forming close bonds with other members. When competition for resources is at hand, tension is released through the rubbing of genital areas. With the use of sex as a method to relive aggression, bonobos are able to be at peace with not just individuals in their community, but also complete strangers. Specifically, communities at sites in Wamba and later in Lomako Forest have proven that intermingling between bonobo groups has resulted in peaceful sexual exchanges between females and tolerance between males. Bonobo behavior demonstrates the emphasis on maintaining harmony rather than using violence to maintain social order. Sexual rubbing is not exclusive to females; both males and females use it as a form of resolving conflict. Bonobos engage in sex with every partner combination: male-male, male-female, female-female, male-juvenile, female-juvenile, and juvenile-juvenile. Despite all this sexual activity, the bonobo species rate of reproduction is low (single birth in five-year intervals) and, to prevent incest, adult females instinctively leave their communities in search for new mates. This hap- 


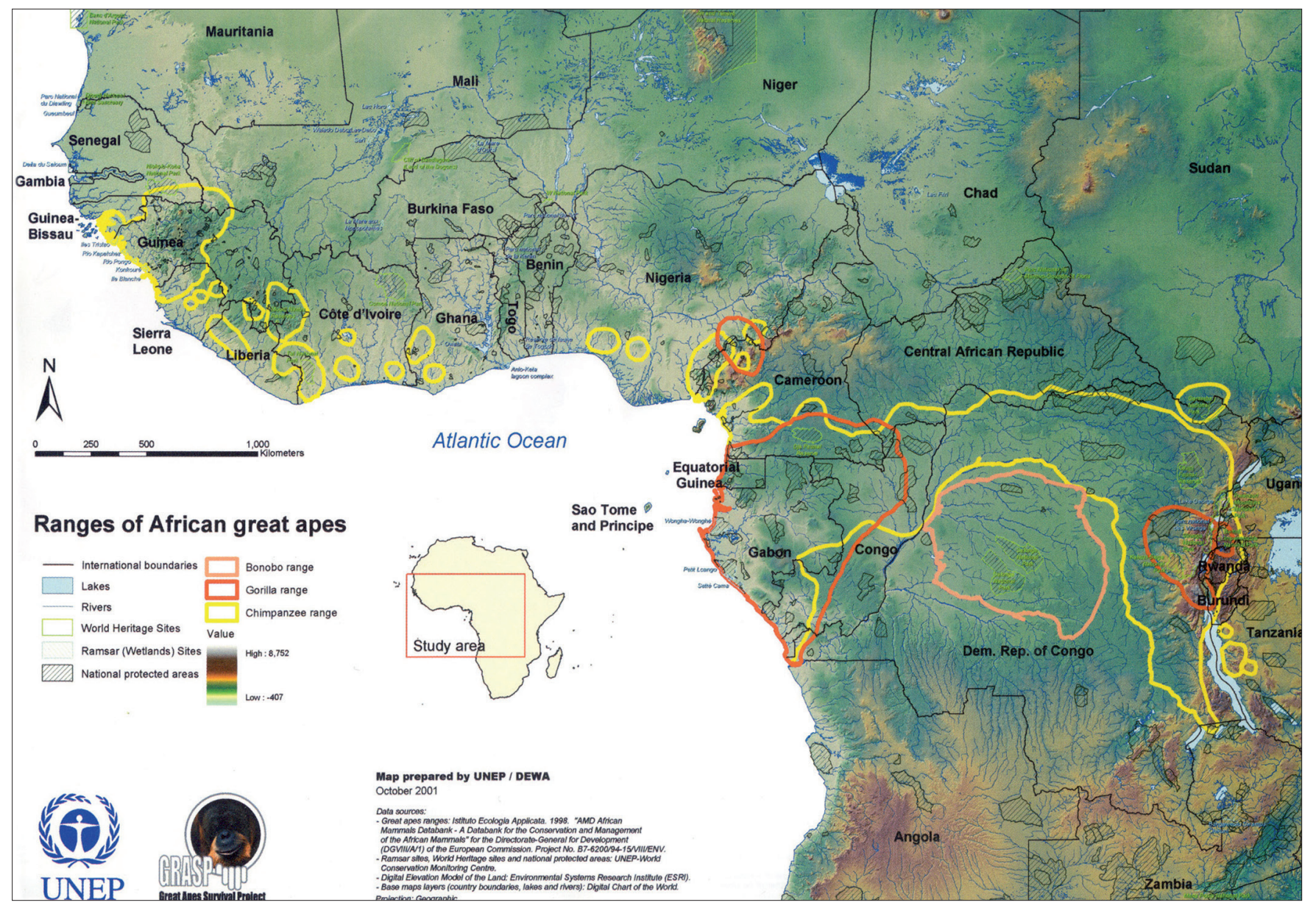

Fig. 5. Current map of Pan species population range from JaneGoodall.org.

pens when females migrate in their adolescent years, leaving their natal group around the age of seven, when they develop their first signs of sexual swelling.

In bonobo societies females maintain their sexual swelling when pregnant, which makes it difficult for males to determine if it is their offspring. This ambiguous pregnancy, while making it difficult for females to find a dependable father figure, promotes a continued unified community; males are not competing with other males for access to females and this limits incidents of infanticide. If a male cannot be sure which offspring are his, then he is less likely to invest any time or energy caring for an infant. It is because of this lack of certainty that the entirety of parental care in bonobos is assumed by the mothers (de Waal, Lanting 1998). That is not to say that adult males are not attentive to infants in the unitgroup. In fact, there is very little aggression directed toward bonobo infants. This is a contributing factor in minimal aggressive interactions among adult male bonobos; there have been no reported acts of infanticide (de Waal 2005). It is thought that extended sexual swelling in bonobos, compared to chimpanzees, lowers competition among male bonobos for access to females for mating.

Sex is an act of pleasure and a form of bonding for both bo- nobos and humans. In humankind, there is clear division between our social lives and sex. Natural selection in humans has promoted pair-bonding rather than promiscuity. Our ancestors had to adapt to the environmental pressures of the African savanna. Nuclear families emerged out of this need for males to protect offspring and female care takers. Greater male involvement in child care has limited sex outside of the nuclear family which was in turn shaped our social order. Society has revolved around exclusive partnerships and the development of moral codes stressing the importance of being faithful. As human history has shown, taming sexuality has been an obsession for ideal cooperative breed but being faithful has been imperfect due to temptations to fulfill our sexual desires.

At this time, bonbos have only been studied in the deep rainforests of the Congo basin. It is unclear just how large their distribution is and also if bonobos only live in tropical forests. Recent observations are testing these assumptions. In the Lukuru region, located in the south of the Democratic Republic of Congo, studies have shown that they can live in a mosaic forest with large savanna areas. Myer Thompson has even observed bonobos feeding on grass on the savanna and also venturing into swamp areas. When spotted in swamp 
regions, bonobos are walking bipedally into waist-deep water in either streams or pools.

These observations show unexpected behavior and also demonstrate the diversity in behavior based on environmental conditions. In terms of studying bonobos, it is important to keep in mind that as science continues to identify new populations and performs lengthy studies on groups. Researchers can truly understand the full capacity of bonobo behavior. The knowledge we have about bonobo social behavior stems from a few captive colonies (Yerkes and the San Diego Zoo), which may have biased our knowledge of bonobos.

\section{EVOLUTIONARY INTERPRETATION OF BONOBO BEHAVIOR}

Field research on bonobo social behavior still lags behind the work done on chimpanzees. While the data obtained at this moment is behind, much attention is being put toward this species. Bonobo communities practice social behavior that is both unique and diverse to its Pan counterpart. Both species are rich in diversity and there is still much to learn about these unique pongids.

Female dominance in bonobos is entirely unique to great ape social behavior. Bonobos provide an alternative view of what is considered natural social behavior. This species demonstrates that evolution does not consistently promote the development of a patrilocal society. Males of any species naturally try to monopolize females, but female bonobo promiscuity has made it extremely difficult to do so; males have no incentive to fight for females. As a result, in cases of intergroup mingling, bonobo males do not have the territory competition present in chimpanzees.

The common belief by science has been that monogyny has been the reason why Homo sapiens sapiens survived; this theory promotes the notion that males naturally felt it necessary to protect their offspring in order to promote the passing of their own genetic traits. As a result of ensuring reproductive success, males would form close ties with their female counterparts. This social behavior was believed to have promoted the formation of the nuclear family in which a male, female, and child live as a cohesive unit. In contrast, bonobo society is maintained through female solidarity. Without a deliberate effort to reconcile tensions, females would be unable to control communities.

We are unable to demonstrate that there is a social model that proves that humans are closest to chimps or the bonobos. The bonobo is a species that allows humans a glimpse at another way of living: "Bonobos show us the conditions under which peaceful relations between groups may evolve" (de Waal 2005). This difference in perspective prevents humans from making universal assumptions about the past. For humans to truly understand where they came from, we must be able to learn not only about our evolutionary history, but also about the social and evolutionary history of our closest relatives, the chimpanzee and bonobo.

\section{A SHARP CONTRAST IN SOCIAL BEHAVIOR}

Over 2-3 million years of separation has caused both species to endure environmental pressures which shaped social behavior. The Congo-Zaire Walaba River and the Kwa-Kasai-Sankuru River is a geographical barrier which prevented the continued interbreeding of these populations. Apes are not known to swim, though bonobos and chimpanzees have been seen wading into waist-deep water (Boesch et al 2002). It became a selective advantage for male chimpanzees to be aggressive, selfish, and territorial because of the lack of resources. Possessing control of food and mates resulted in close bonding between males. In contrast, male bonobos who also remain in their natal communities never developed close male bonding because of the abundance of food sites and mates. As a result, natural selection shaped bonobo social behavior to develop interpersonal skills.

Bonobo hierarchical structure is less fluid in comparison to their chimpanzee counterparts. As stated earlier, the most critical coalition in bonobo society is the one between mother and son. This close bond limits ambitious males from climbing the social hierarchy. Bonobo males "lack the ever-shifting, opportunistic alliances capable of prying open a system" (de Waal 2005), which are present in chimpanzee males.

While both chimpanzees and bonobos have policies regarding how a society should function, both are dramatically different. Chimpanzees follow a method of knowing what they want, when they will get it, and how they will get it. Bonobo's are not less intelligent, but they simply use different methods to obtain what they want.

Chimpanzees resort to violence to obtain what they want, while bonobos use sex to solve problems. Chimpanzee social behavior is patrifocal; males form coalitions to obtain resources through the use of violence. Bonobos are sympathetic, possessing interpersonal skills that allow them to be in touch with their personal emotions while also having the neurological development to perceive distress in others (Rilling et al 2011). With this awareness, bonobos are able to share an understanding without becoming consumed with their own egocentric desires.

\section{AGGRESSION AND NON-AGGRESSION IN HUMANS}

Frans de Waal $(2005 ; 2009)$ states that there is a dialectical process taking place in evolution between the desire to compete and the need to cooperate. Roughly five to six million years ago, our species shared a common ancestor with both bonobos and chimpanzees. Evolutionary anthropology's goal is to determine the factors that make humans unique and also to find homologous behavioral characteristics in our closest living relatives (Mitani 2009). Humans are a product of both their evolutionary past and modern civilization. There is a paradox in the very nature of what it means to be human. The biological makeup and social behavior of humankind are in a constant dynamic process. Humans anatomically and 


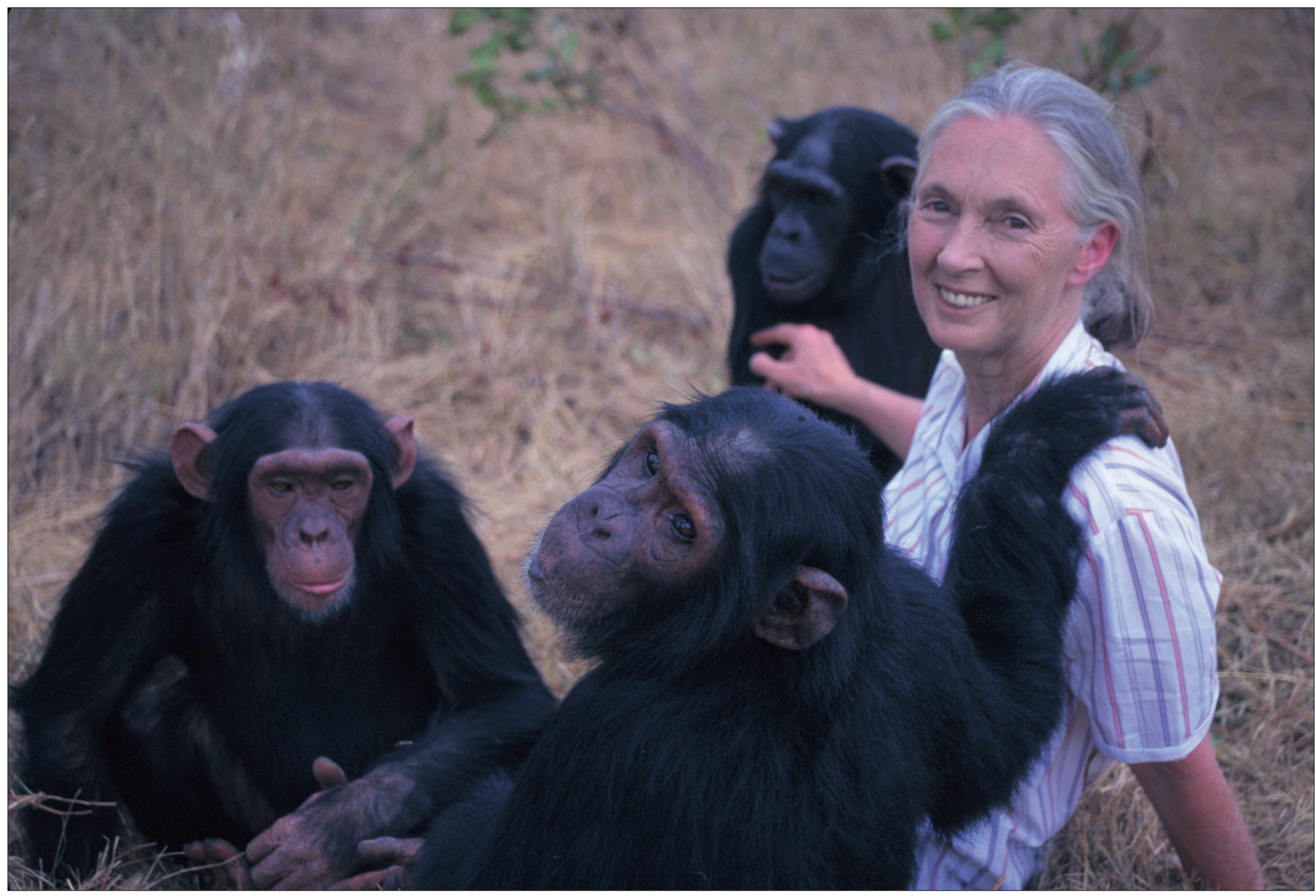

Fig. 6. Jane Goodall sitting with chimpanzees. Photograph by Michael Neugebauer from Jane Goodall's Wild Chimpanzees Media Center.

neurologically have emerged into a species with a specialized complex brain capacity. The brain is a problem-solving organ. In cases of difficulty, it is a source of an imagination that implements the planning of actions which can result in varying outcomes.

In terms of sharing similar biological material, Homo sapiens sapiens and the Pan species share 98.8 percent of some DNA sequences (Furuichi et al 2008), making the chimpanzees and bonobos our closet living relatives. This figure refers to the results of DNA hybridization. Geneticists count the total number of DNA letters that match each other within the respective human and Pan genes. Researchers test the strength of DNA base pairs through the action of gradual heating past the melting point that DNA can withstand. The point where two helices separate is 85 degrees Celsius. Since human and Pan DNA are not identical, the degree of separation is not perfect to the anticipated break point of 85 degrees Celsius. Richard Dawkins clearly states that "the difference between the melting point when a strand is bonded to one of its own kind, and the melting point when it is bonded to a strand from another species, is our measure of the genetic distance between the two species. As a rule of thumb, each decrease by 1 degree Celsius in the 'melting point' is approximately equivalent to a drop in 1 per cent in the number of DNA letters matched".
Killing a member of one's species is an ultimate selfish and egoist act, because it eliminates individual fitness. Murder is a part of what it means to be a human. Humanity denies acts of cruelty because individuals naturally accept that since we are rational beings, we are exempt from the natural tendencies to kill. However humans, like all species on this planet, will seek any means necessary to survive. Killing is just one of many methods of overcoming difficult problems. Many humans struggle to understand that they are a product of evolution and out for their own personal agendas.

Evolution theorists like Richard Wrangham and David Smith claim that our species is deceived by our subconscious. Our desires to cause homicidal actions overpower our desires for compassion. With the brain's ability to cloud rational judgment, we have a justification for killing while allowing us to believe "that humans are still compassionate, moral and pious people" (Smith 2009). The unconscious functions of the brain allow for actions beyond our control. The fight or flight syndrome is a subconscious act brought forth by the brain to increase self-preservation. Our brain is composed of many intricate parts that are interrelated with one another to provide the body for functioning in a state of homeostasis. Interference competition is taking place in the brain. Parts of the brain in each person are competing to express their in- 
formation. Emotions affect the psyche of an individual and, as a result, not all parts of the brain function together equally. Smith (2009) states that some parts of the brain are repressed or withhold information from a person. If the mind is able to deceive itself from believing that it has truly caused harm to another human, then this will directly increase the chances of a person's survival and reproduction.

Self deception is an adaptive trait that has survived the evolution of the brain. This is a result of circumstances that made it beneficial for humans to be deprived of information. Without involuntary reaction, humans and other species would be unable to survive. It seems ideal for us to have total access to information, in order for us to make the most logical and rational assessment of a situation. On the contrary, there are situations where it is to the benefit of a person that they lack the ability to use reason because a decision needs to be immediate. In particular, it is advantageous to lie to another person in order to preserve oneself. The brain withholds information from persons in order to protect itself from being reprimanded for its dishonest actions.

The brain is a product of evolution, not a result of morality. It is a problem-solving tool with the sole goal of survival. Evolutionary history has shaped behavior which, as a result, has given humankind the propensity to both kill and love. Our natural environment has fostered the need for cooperation, as well as the ability to commit acts of violence. Throughout time, coalitionary bonding in early hominids made it more difficult to use murder as an effective means of solving problems within society. It was more of a risk to fitness if a mating rival was eliminated. Australopitchecines were neither bold hunters nor cannibals. This early hominid was a scavenger who was in constant fear for its existence. The evolutionary development of the brain was selective according to the pressures of its environment. It became a selective advantage for hominids to possess a complex mental capacity to outsmart large competitors. With advances in cognitive function, tool usage, cooperation, gesture calls, and proto-language emerged to augment limitations in size. Individuals banded together to gain access to resources that would otherwise be impossible to obtain. Through repetition and early forms of communication, creativity in the brain allowed early hominids the ability to develop and utilize special tools and tactics. As a result of this expansion in the neo-cortex, humans have the exceptional ability to think creatively within the limits of their natural environment. Innately, humans are social beings that rely on one another to survive in order to live productively in the modern world. Deterrents to kill developed through time in communities as a result of the creation of alliances and friendships, as well as the elimination of those individuals that cause psychological and social unrest. These acts were established for the general welfare of our species. The notion of morality emerges out of this need to establish social order. This is especially true where the act of killing is condemned in the modern world. Humans have become more and more civilized as a refined species and, consequently, they have developed more effective deterrents to murder, which have been established in particular by legal systems and through improving cultural conditions Evolutionary psychologist David Buss argues that moral law has provided structure and order in a world where individual interests had once outweighed the collective good. Our understanding of human social behavior has not been fully achieved. However, studying the range of social behavior in chimpanzees and bonobos does provide researchers with the ability to rationally speculate about our remote ancestors because our own species has descended from ape-like forms in the evolutionary past.

\section{CLOSING REMARKS}

Human behavior is an accentuation of both bonobo and chimpanzee social behavior. We have the ability to commit extreme acts of genocide and possess the moral-decision making skills to set aside individual interests for conflict avoidance. We are social animals dependent on one another in order to survive; connecting with members of our species is hardwired in us. Emotions play a crucial role in our daily decision making; the connections we form with others is what distinguishes our species. We are not purely cerebral, void of subjective preferences. As a result, humans are extremely conflicted primates that are constantly in a state of finding order between selfish desires and moral good. Recognizing this range in social behavior is vital to us for coming to terms with our place in the natural world; humans are not separate from the environment.

Human populations have expanded exponentially over the past century, which has brought about the most dramatic environmental changes to primate habitats. As humans have expanded into these environments, we have infringed on primate communities which has lead to the destruction of habitats. In order for chimpanzees and bonobos to continue to exist in the wild, we must alter our habits. For millions of years, ancestral chimpanzees and bonobos adapted to the environmental conditions of their natural world. However, human activities are so dramatic that structural and behavioral adaptations cannot develop fast enough in order to counteract these changes.

It is crucial that we protect these endangered species. Studying our closest evolutionary cousins not only allows us to gain insights into the social behavior of primates, but also holds a key to understanding how to combat infectious diseases such as HIV. Educational campaigns in communities where primates are located can greatly bring about dramatic change to a region.

Primatologists in the last 20 years have become progressively more involved in conservation. Both primate research and conservational practices have become interdependent. Knowledge of primate behavior directly contributes to establishing the most effective conservation strategies; while effective primate conservation strategies will lead to the continued existence of these Pan species. Conservation efforts must be custom-tailored to specific populations if they are to 
have any chance of success. Protecting primate populations requires a systematic approach in which accountability is needed across the board. Cooperation from all members of society is vital. This includes international, national, and local people abiding to principles for preserving these endangered species. In order for widespread support for the conservation of primates, local support is crucial.

\section{ACKNOWLEDGMENTS}

The preparation of this article was inspired by my distinguished professor Dr. H. James Birx. His guidance and insights have once again motivated me to share my passion for evolution studies and primate behavior with the academic community.

\section{LITERATURE}

Boesch, C., Hohmann, G., Marchant, L. F. (2002). Behavioural Diversity in Chimpanzees and Bonobos. Cambridge: Cambridge University Press.

Darwin, C. (1871). The Descent of Man and Selection in Relation to Sex. London: John Murray.

Dawkins, R. (2009): The Greatest Show on Earth: The Evidence for Evolution. New York: Free Press.

de Waal, F. (2009). The Age of Empathy. New York: Random House, Inc.

de Waal, F. (2005). Our Inner Ape. New York: Riverhead Books.

de Waal, F., Lanting, F. (1998). Bonobo: The Forgotten Ape. Berkeley: University of California Press.

Fawcett, K., Muhumuza, G. (2000). Death of a Wild Chimpanzee Community Member: Possible Outcome of Intense Sexual Competition. American Journal of Primatology 51: 243-247.

Furuichi, T., Thompson, J. (2008). The Bonobos: Behavior, Ecology, and Conservation. New York: Springer.

Goodall, J. (2000). In the Shadow of Man. New York: Mariner Books.

Goodall, J. (1986). The Chimpanzees of Gombe: Patterns of Behavior. Cambridge: Belknap Press.

Jensen, K., Hare, B., Call, J., and Tomasello, M. (2006). What's in it For Me? Self-regard Precludes Altruism and Spite in Chimpanzees. Proceedings of the Royal Society B 273: 1013-021.

Mitani, J. C. (2009). Cooperation and Competition in Chimpanzees: Current Understanding and Future Challenges. Evolutionary Anthropology 18: 215-227.

Rilling, J. K., et al. (2011). Difference Between Chimpanzees and Bonbos in Neural Systems Supporting Social Cognition. Social Cognitive and Affective Neuroscience doi:10.1093/scan/nsr017.

Silk, J. B., et al. (2005). Chimpanzees are Indifferent to the Welfare of Unrelated Group Members. Nature 437: 1357-1359.

Smith, D. L. (2009). The Most Dangerous Animal: Human Nature and the Origins of War. New York: St. Martin's Griffin.

Strier, K. B. (2007). Primate Behavioral Ecology. 3rd ed. Boston: Pearson Allyn and Bacon.

Watts, D. P. (2003). Male Dominance Rank and Mating Success in an Extremely Large Chimpanzee Community at Ngogo, Kibale National Park. Am J Phys Anthropol 36 (suppl): 221.
Watts, D. P., Mitani, J. C. (2004). Intracommunity Coalitionary Killing of an Adult Male Chimpanzee at Ngogo, Kibale National Park, Uganda. International Journal of Primatology 25.3: 507-22.

Whiten, A., Goodall, J., McGrew, W. C., Nishida, T., Reynolds, V., Sugiyama, Y., Tutin, C. E. G., Wrangham, R. W., Boesch, C. (1999). Cultures in Chimpanzees. Nature 399: 682-685.

Wilson, M. L. (2003). Intergroup Relations in Chimpanzees. Annual Review of Anthropology 32: 363-392.

Wrangham, R. W. (1999). Evolution of Coalitionary Killing. Yearbook of Physical Anthropology 42: 1-30.

\section{FURTHER READINGS}

Birx, H. J. (2010): Biological Anthropology. In: Birx, H. J. ed., 21st Century Anthropology: A Reference Handbook. California: SAGE Publications, Vol. 1: 2-12.

Fouts, R., Mills, S. T. (1998). Next to Kin: My Conversations with Chimpanzees. New York: Harper \& Row.

Savage-Rumbaugh, E. R. Lewin. (1994). Kanzi: The Ape at the Brink of the Human Mind. New York: Wiley.

Stanford, C. (2007). Apes of the Impenetrable Forest: The Behavioral Ecology of Sympatric Chimpanzees and Gorillas (primate field studies series). Virginia: Prentice Hall.

Trubits, R. J. [In Progress] From Primate Communication to Human Language: Anthropological \& Philosophical Speculations. Humanism \& Posthumanism [Festschrift honoring Dr. H. James Birx]. Germany: Peter Lang.

Trubits, R. J. (2010): Primate Research Studies. In H. J. Birx (Ed.), $21^{\text {st }}$ Centu ry Anthropology: A Reference Handbook. California: SAGE Publications, Vol. 2, Chapter 63: 633-646.

Trubits, R. J. (2009): The Hominid-Pongid Split. In H. J. Birx (Ed.), Encyclopedia of Time. California: SAGE Publications, Vol. 2: 675-677.

\section{AUTHOR}

Ryan J. Trubits received a B.S. degree with honors from Canisius College in Buffalo, New York, majoring in both anthropology and history, with a minor in philosophy. The recipient of the national Eugene Buechel Award for excellence in anthropological achievements, he focuses his research on hominid-pongid evolution, the emergence of language, and primate behavior. His interdisciplinary education included a semester of study at the National University of Ireland, Galway, as well as academic experiences in holocaust history in the countries of Poland, the Czech Republic, and Germany. This year, as an AmeriCorps VISTA member, Ryan utilized his talents in writing grants for educational institutions. Most recently, Ryan was accepted by the Peace Corps. During his service in Guinea, he will provide health education to impoverished communities, develop technical skills in applied anthropology and conduct ethnographic studies. Continuing his pongid research, Ryan aspires to enlighten the interested public on the interconnectedness between the apes and our own species in terms of comparative biology and primate evolution. 
